\title{
Chapter 8 \\ Out of Print. A Historiography \\ of the South Saami in Regional \\ and National Works of History
}

\author{
Leiv Sem
}

\begin{abstract}
This chapter discusses how the relationship between the Saami and majority non-Saami population in Norway is negotiated in the public domain, and what premises and assumptions that currently govern these negotiations. The point of departure is a three-volume history of the Trøndelag region. This 2005 publication resulted in a heated public and academic debate, as representatives of the Saami population criticized the volumes for writing the Saami people out of the history of the region. Both the three-volume history work and the ensuing debate are examples of how national and cultural identities are products of cultural and textual practices. They are not fixed and final, but under constant negotiation, and a continuation of a process that may be traced back to mediaeval times and beyond, and similar processes may be found across the globe. Against this backdrop, the academic and public debate of this work of regional history is analysed applying methods adopted from critical discourse analysis.
\end{abstract}

Iktedimmie Jaepien 2005 Trööndelage-dajven histovrije bæjhkoehtamme sjïdti 3 gærjine jïh destie akte baahkes byögkeles jïh akademihkeles digkiedimmie sjidti, dan åvteste tjirkijh dejstie saemien årroejijstie leejhtin daah gærjah saemide histovrijen sistie tjeelin. Tjaelijh jïh bertijh daan barkoen duekesne vaestiedin saemieh lin meatan vaaltasovveme dan gåhkese doh gaavnoes gaaltijh dam luhpiedin. Vååjnoe goh daate vuajnoe lea aktene vihties sjïere dåehkesne mij åajvahkommes siebriedahkem goh krïevenassh akten akademihkeles histovrijasse. Ajve dah mah leah tjaaleldh gaaltijh tjaaleme meatan vaaltasuvvieh dej tjaaleldh gaaltiji sïjse. Dovne dihte vierhkie 3 gærjajgujmie jïh minngebe digkiedimmie vuesiehtieh guktie nasjovnaale jïh kultuvrelle identiteeth leah illedahkh kultuvrelle jïh tjaaleldh praksiseste. Dah eah leah staeries jïh ihkuve, men aktene ahkedh rååresjimmesne, jïh guhkiedimmie aktede prosesseste maam maahta dåeriedidh bååstede gaskoehaaltarasse jïh guhkiebasse, jïh plearoeh prosessh maahta abpe veartenisnie gaavnedh. Daan duekien vööste edtja dam akademihkeles jïh byögkeles digkiedimmiem Trööndelagen histovrijen bïjre analyseradidh, jïh vuekieh nuhtjedh mah leah nænnoestamme aktede laejhtehks tjaalegeanalyjseste. Dan mænngan daate gyhtjelasse jarngesne: guktie tsiehkiem

\footnotetext{
L. Sem $(\bowtie)$

Faculty of Education and Arts, Nord University, Levanger, Norway

e-mail: leiv.sem@nord.no

(C) The Author(s) 2019

H. Hermanstrand et al. (eds.), The Indigenous Identity of the South Saami,

https://doi.org/10.1007/978-3-030-05029-0_8
} 
rååresje gaskem saemieh jïh jienebelåhkoen daaroeh Nöörjesne byögkeles suerkesne, jïh mah premissh jïh nuepieh rååresjimmide daelie stuvrieh?

\subsection{Introduction}

When a new three-volume work on the history of the Trøndelag region was launched in Norway in 2005, the volumes were received with ovations. The county officials who had ordered the work three years earlier were delighted and encouraged all citizens to read it to understand 'how we have become who we are' (Engen 2005). The chief editor, historian Ida Bull, presented the volumes thus: 'This work of history is written for everyone interested in Trøndelag's history' (ibid.). There were some opposing voices, however. Most prominent among these was the Saami historian Sverre Fjellheim, who accused the editors of lacking basic knowledge, and for having constructed a narrative based on lies, myths and prejudice. From a Saami point of view, it would have been better if they had not been included at all in this work of history, he exclaimed (Fjellheim 2005). Saemien Sijte, the South Saami cultural centre concurred: 'The treatment of the South Saami in [this work of history] undermines everything we are working on. We are outraged, sad and disheartened over the publication of such a text today. This work of history will stand on the bookshelves in the region and contribute to knowledge and attitudes towards Saamis for generations to come' (Saemien Sijte 2005). The aim of this chapter is to analyse some of the conditions that underlie the presence of two such opposing views in a relatively small community such as the Trøndelag region, and to analyse the machinations of the discourse of history through a reading of 'The History of Trøndelag' as a negotiation of identity, belonging, and power.

To the South Saami community, it was no surprise that the publication of these volumes would leave them intensely dissatisfied. As soon as the decision was made to have an 'official' history of the region written, Fjellheim and other Saami historians had made it known that they wanted to be a part of this project (Skjesol 2002; Fjellheim 2005). All too often they had experienced that works of history sided against the Saami, downplaying their role in the development of Norwegian culture, and neglecting or even disputing their continuous habitation of these territories. In some cases, historians had even been called as witnesses in court trials, investing all their professional authority in farmer's claims to land used as reindeer pastures by the Saami (Hermanstrand 2009, 487). The professional historians were not equipped to write a total history of the region, the Saami historians claimed. However, this was turned down by the editors and the working group appointed to do the work. They felt they had necessary and sufficient expertise. Furthermore, they added, what they wanted was a comprehensive and full account, not biased and partial stories (Bull 2002; Fjellheim 2005). To give such an account, the professional, academically trained historians were the best and ablest. This was certainly the attitude of the editors, who obviously regarded themselves unquestionably capable of handling this part of the history. In fact, it was stated as the very goal and purpose of these 
volumes to try to discuss the history of the region as a multitude of different cultures and identities. When the commissioning of the book was presented to the public of this region, it was with the words: 'One main goal of the book is to illuminate the identity of the 'Trønder' [i.e. the inhabitants of the Trøndelag region]' (Skjesol 2002). In the preface to the book, the editor, Ida Bull, states that the authors did not intend to give a final answer to the question of the 'Trønder identity', but rather to scrutinize and question this identity. The goal is: to "express what it has been like to be man or woman, child or elder, fisher, farmer or Saami in Trøndelag at different points in time' (Bull 2005a, b, 12). As late as 17 February 2017, when the question of the absence of Saami history was raised again in conjunction with the Centennial for the first National Saami congress, the editors yet again took to the newspapers, advocating that ideologies or perspectives had nothing to do with this: 'the problem here is the lack of sources in a period before the sixteenth and seventeenth centuries [...] The answer to what happened in this period lies not in political decisions but in extended research' (Bull 2017).

It is probably a fair assumption to make that Fjellheim's harsh criticism, as well as his suggestions of Saami cooperatives, would strike most non-Saami readers as unreasonable, unfair and biased. To the degree that one gives the Saami some thought at all, most Norwegians would most likely be inclined to consider the unfair treatment of the indigenous Saami population as a thing of the past. Do the Saami not have their own Parliament? Did not His Majesty King Harald V apologize for the way the Saami have been treated by the Norwegian government at the opening of this Saami Parliament in 1997? The King then uttered: 'The Norwegian state is founded on the territory of two peoples-Norwegians and Saami. Saami history is tightly interwoven with Norwegian history. Today we must apologize for the wrongs inflicted by the Norwegian state onto the Saami people through a harsh policy of Norwegianization'. ${ }^{1}$ For most Norwegians, such apologetic words and actions represented a perhaps exaggerated atonement for past mistreatment. These words also marked a general benevolence towards the Saami, and probably strengthened an already established self-image of Norwegians as progressive, liberal and observant of the rights of indigenous peoples, both at home and abroad. According to the political scientist Øyvind Østerud, the unclear links between a colonizing history and an apparent selfless policy of foreign engagement has promoted the idea that 'the Norwegian self-image is intrinsically innocent' (2009, 140, italics in orig.) This self-perception is nurtured by the images and reports of how other societies are treating their own indigenous populations. In a shrewd manoeuvre, the apologetic gesture towards the Saami people makes it possible for Norwegians to profit on the progressive-liberal recent history, without taking into account the content and the historical background of it. This is a manoeuvre of the blind eye, and in this chapter, I will show how this blind eye works, even in Norway, and even to this very day.

\footnotetext{
${ }^{1}$ See https://www.nrk.no/sapmi/_-kongens-ord-betyr-mye-for-samene-1.11966176. This and all translations from Norwegian by LS. Orig.: «Den norske stat er grunnlagt på territoriet til to folk - nordmenn og samer. Samisk historie er tett flettet sammen med norsk historie. I dag må vi beklage den urett den norske stat tidligere har påført det samiske folk gjennom en hard fornorskningspolitikk.».
} 
In the following, I intend to investigate which role and status the South Saami are given in the textual totality of word choices, arguments and thematical priorities in Trøndelags historie (hereafter TH 1-3). ${ }^{2}$ I read this as a rhetorical structure and political document, while also considering the societal context within which it is written. Methodologically, I apply the Critical Discourse Analysis approach developed by Norman Fairclough (2003). This school of thought aims to investigate the ideologies that lie behind the text, hidden in the structure and patterns, and the way the text works upon the social, outer reality. As the text in question is a historical narrative, I have supplemented Fairclough's terms with perspectives and terms from narratology (Bal 1997). I have read the three volumes closely, paying particular attention to the mentioning and omitting of the South Saami. I have studied the hermeneutic interplay between details of the text and the larger structure, with the aim of identifying the ideologies and suppositions that inform, support and frame the text-and guide the readers through the history and through the Trøndelag of today. I must also confess I at times have read these volumes with a degree of suspicion. I find this fully justified, because if there is a potential in the text for readers to see it as, for example, claiming that the Saami arrived in certain areas just recently, well- then one can assume that this potential will in fact be realized by many readers. Therefore, a kind of consciously malevolent reading may be in order to bring about reflections on the potential effects of the text. I wish to point out that my interest here will not be directed at the intentions or attitudes of the individual authors. My focus will be to question the effects the rhetorical patterns of details and structures may inflict or confer on the readers. What I am addressing here is therefore a certain historiographical discourse. The term discourse is an attempt to grasp the basic, often unsaid suppositions that make some concepts uncontested, evident and natural, and out of reach of the political domain. In this way, these suppositions determine what one may think or utter on a given subject, as they also determine who is given authority to speak or be heard (Fairclough 2003, 58). I am not saying that the ideology of the writers is not important here. However, in the perspective of discourse analysis, the text is not merely an impression of the writer's ideologies or intentions; it is to a large degree governed by the institutionalized concepts and practices of the historians and their guilds, e.g. their routines for work organization, recruitment and quality assessment. The Trøndelags historie volumes are not an isolated work, but a specimen of a genre and the expression of a scholarly culture and a national culture. These are the real subjects of this study.

\footnotetext{
${ }^{2}$ This chapter is an elaboration of an article published in the Norwegian journal Heimen (Sem 2017).
} 


\subsection{A Historiographical Context}

The topic of the eradication of indigenous populations in works of history is, obviously, not an exclusive Norwegian phenomenon. Rather, it has its parallels across the globe. The writing of history is in fact a very powerful and therefore central way of establishing rights and taking control over territory. Writing about indigenous history, the New Zealander Linda Tuhiwai Smith points out how the systematic exclusion in the writing of this history worked alongside the actual material redefinition that took place 'simultaneously through such things as the renaming and 'breaking in' of the land, the alienation and fragmentation of lands through legislation, the forced movement of people off their lands, and the social consequences which resulted in high sickness and mortality rates' (Smith 2012, 34). In her study of New England historiography, historian Jean O'Brien identifies four main narrative strategies for erasing indigenous populations, thereby making the writing of history a primary means of asserting authority and control over colonialized land (O'Brien 2010). The first strategy is to present the colonialist as the first to ever establish institutions and so on, e.g. the first to 'really' take hold of the land. In this way, the indigenous population is not merely erased, as a basic premise, but a certain presumption of 'modernity' is also established which implicitly denies non-Westerners a place in the history. The second strategy is the 'replacement narrative' which insists that the colonizers have replaced the indigenous people, typically by 'remembering' them through erecting monuments or applying place names. Such a move places the original inhabitants in a far-off past, but also structures the space and landscape and readies it for the colonizer's rule. The third strategy is the constant preoccupation with the 'last of its kind'. This insistence, often elegiac, on a vanishing culture is typified by Fenimore Cooper's Last of the Mohicans, and seemingly demonstrates the extinction of a culture and implicitly argues that any descendants are not real or authentic. These strategies are sometimes carried on the sleeves of the texts through explicit statements. At other times they are hidden, perhaps even to the authors themselves, carried by unconscious suppositions. Often the texts are a mesh of conflicting statements, e.g. reports of Native American attendance at events commemorating the lost people (O'Brien 2010, p. 145f). 'Strategy', then, does not necessarily entail conscious manoeuvring in order to achieve an objective, at least not on the level of each individual writer. On a structural level, though, one has to discuss the way that the overall patterns produced by the large bodies of texts serve the interests of the non-indigenous peoples.

Moving to the Norwegian context, many works of history explicitly deny a Saami presence or try to delineate it in time or space. There is a steady stream of historical accounts claiming that the Saami people have arrived relatively recently within the borders of Norway of today, or that they 'originally' have occupied but a small area, and only in fairly recent times have widened their territory. Accounts such as these are published on a weekly basis as part of an ongoing debate on rights to land and resources on websites, the debate columns of newspapers and even books from more or less established publishers. In our context, it is of more interest 
to see how these themes are handled by historical authorities in the field. In the tradition of the nation-builders of the romantic period, Norwegian historians of the twentieth century have conventionally focused their narratives of the past on the free, independent farmer. This thematic bias led two of the most prominent historical scholars of central Norway, Jørn Sandnes and his disciple Kjell Haarstad, to write several works where they argued for the primacy of the farmers over the Saamis' longevity and rights to land (e.g. Sandnes 1972; Haarstad 1992). It was their support of the so-called 'advancement of the Saami' theory that was used as evidence in the court of law in the case referred to above. This perspective also guides the accounts in more recent works of authoritative history, and on a national level. Take, for instance, the six-volume work Norsk historie ['Norwegian history'] published by the esteemed publishing house Det Norske Samlaget in 1999. The first volume, covering the period from 800 to $1300 \mathrm{CE}$, does not mention the Saami at all; neither 'same' nor 'finn' is listed in the index (Sigurðsson 1999). The second volume mentions the Saami ['samar'] four times, each time merely in passing, and each time regarding the northernmost parts of Norway, never Trøndelag (Ersland and Sandvik 1999). The third volume covering the period 1625-1814, devotes one single page of about three hundred to the Saami population, and apart from this, they are hardly mentioned at all (Dyrvik 1999, 80 et pass.). The index for the fourth volume covering the short period following independence and to the constitution (1814-1860) mentions the Saami ten times. The author of this volume makes a point out of the regrettable lack of sources on Saami history (Pryser 1999, 70). However, he does not seem to have made use of the most of those that actually do exist as he never tries to portray their lives or perspectives on life in the Norwegian state. The fifth volume, dealing with the period up to 1914, follows the history almost until the first National meeting of the Saami in 1917, but does not mention the Saami community or their predicaments at all (Nerbøvik 1999). Only in the last volume covering the years up to 2000 are the Saami mentioned in a number of sub-themes encompassing the establishment of Saami organizations, Acts and institutions (Furre 1999, 606). This fairly recent and comprehensive work of history was written in part for university students and in part for the general public. It has been revised several times, the last revised edition being the one cited above, and has been widely used at the most prestigious Norwegian universities. As such, it may be said to represent a common and general conception of the national history — and of the Saami people's place in it.

\subsection{The Three-Volume Work Trøndelags Historie}

How does the work of history, Trфndelags historie, fit into this picture? Recently written, and dedicated to a region with a vital and culturally distinct indigenous population, one ought to expect quite another take on history. Are the Saami, then, indeed recognized as an integral part of the community? Are they seen and treated as Saami? As Norwegians? Or as both concurrently-is that possible? And may one 
surmise the status of the South Saami in Norwegian society today from reading this book?

The volumes were written on the joint request of the county authorities in both North and South Trøndelag. ${ }^{3}$ Upon this request, NTNU University in Trondheim put together a team of historians and archaeologists to write the text, and to support them a reference board of experts was established. Fatefully, as mentioned above, they declined Saami requests to be represented among the writers or on the board. It was therefore quite predictable that the volumes were met with harsh criticism both within academic and popular forums as soon as it was published. The criticism from Fjellheim quoted above was followed by historians and archaeologists Jostein Bergst $\varnothing 1$ and Gaute Reitan, among others. These scholars claimed that the South Saami were written almost entirely out of the history of the region, and that the volumes tended to support the theory of late advancement of the Saami, which, they argued, was ideologically biased and empirically outdated (Bergst $\varnothing 1$ and Reitan 2008, 10). The editors of Trфndelags historie, Ida Bull and Ola Svein Stugu, responded to the criticism by pointing out that the South Saami were in fact included in the work, 'as far as the historical sources permitted'. The critics raised doubts about the presence of the South Saami in these volumes by singling out and quoting sentences out of their proper context, the editors claimed, while 'reading the full paragraphs will give a more balanced picture' (Bull and Stugu 2008, 659).

To be fair: The volumes comprise a collaborative work using 11 authors. These authors treat the matter in question differently. Especially the first part of the first volume and the last part of the third volume obviously have indeed given a fair share of attention to questions of identity and coexistence, and to Saami culture. However, this is not the case throughout the three volumes and the history as a whole. While this division of labour has its upside in gaining variety in both perspective and style, this way of organizing the writing, and such a textual structure, can have its costs. Most notably, the overall responsibility for the representation of certain subjects may be totally undermined. Furthermore, tensions might arise in the totality of the text where the reader is led in unforeseen or unwanted directions. Even if the individual authors do write their part responsibly, the impression of the text as a whole may still do the Saami community injustice.

Let us start with a quick shorthand quantitative analysis. From the index, we see that the Saami are mentioned in only one page out of every 28. Of course, this does not say that the rest of the pages do not relate to or are not relevant to the Saami. But in many instances, the failure to mention the Saami would indeed represent a cleansing of them from history. In the work as a whole, one becomes after a while quite accustomed to the Saami not being mentioned in contexts that could defend, profit or even demand a discussion of them as well as their non-Saami neighbours. One seeks in vain for the Saami in, for example, the chapter on 'Social differences' in the first volume. Likewise, the chapter on 'Economy, Work and Occupation' in the volume on the Middle Ages does not mention the Saami at all. Neither does the chapter on 'Housing and Foodstuff' in the nineteenth century (TH1, pp. 147-152;

\footnotetext{
${ }^{3}$ As of 1 January 2018 the two Trøndelag counties have been merged into one county: Trøndelag.
} 
TH2, pp. 39-53; TH3, pp. 145-169). From the reader's point of view, the specific Saami way of life would of course offer weight and depth, as well as a widened perspective of the concept of society and culture if the accounts of the non-Saami customs had been supplied. Furthermore, the exclusion of this information obviously affects the reader's conception of whether the Saami are part of a 'Trønder' identity.

On the other hand, there are some conjunctural points that are reiterated several times. Possibly this is one of the effects of dividing the writing between multiple authors, or possibly this stems from a wish from the authors' part to make the most of scant sources. Regardless of the reason why one may very well assume that such reiterations might have some sort of impact on the readers. A repetition of a theme may, for instance, be read as a stressing of important points in the narrative, or it may simply function as mnemonic overkill. If so, it would be of interest to check which motif is reiterated. Ominously, the one subject that is most striking among these is the question of conflict between the Saami and peasants. This point is repeated so often that it must have an effect on the reader. In volume II, the conflict motif is found no less than nine times out of the 17 entries on the topic 'Saami' in the index (TH2, pp. 156-57, 159, 265, 287, 300, 303, 306, 352). That is, every second time the Saami are mentioned it is as a party in conflict with the farmers. It seems fair to assume out of these sheer numbers that any reader would have an overwhelming impression of a conflicted and troublesome relationship to say the least, and it would perhaps not be a stretch to surmise that many readers would be inclined to think of the Saami as something of a problem.

And this is the characteristic trait of this piece of history: Large parts of the volumes are written from a clear and far-reaching peasant's perspective. This perspective is expressed not only through the relative amount of representations but also in the type of representations, especially in the second volume. Here the farmers emerge on the pages through close and thick descriptions of their tools, city streets, quarters and their daily lives. Several authors speculate eagerly and vividly about their living customs and social relations. In contrast, the discussion of other people than peasants is purely theoretical. If such people are mentioned at all, it is even more rarely mentioned how they have organized their society and lives. While the omnipresent farmers are almost tangible, the Saami remain a theoretical and vague construct, far less frequently given life and actual representation, and discussed with far less curiosity about what they could be capable of, and with far less interest in pursuing answers. Were the Saami, for instance, interested in building elaborate dwellings? Not likely, according to these writers. Or in tumuli? Also not likely, it is offhandedly stated (TH1, 89 and 248).

It is likewise telling how the authors have structured the paragraphs dedicated to the Saami, few as these paragraphs are. How does one, for instance, open the passage on 'the shift in Saami economics' in the second volume? The very first sentence reads: 'It is particularly in conjunction with the use of uncultivated pastures and the establishment of mountain shielings that the farmers came into conflict with the Saami in the mountains' (TH2, 306). The choice of the farmers as the point of departure or point of perspective in the paragraph reveals where the actual interest of the text lies, as does the grammatical choice of agency. The paragraph continues: '[p]arts of the background of the conflict between farmers and Saami at the end of 
the seventeenth and the beginning of the eighteenth centuries stems from the change in Saami economy [...]' (ibid.). Due to lack of space, we must here leave aside the simplistic dichotomy between 'farmer' and 'Saami' as clean-cut, mutually exclusive categories, a use of terms that most of the writers of TH apply even though it rests on an illogical mix of economic and ethnic-cultural categories. Again the sparse information on the Saami is framed by the degree and manner in which they were relevant to the farmers. This not only guides the interpretation of the information, but it also defines the very value of the Saami. They are not portrayed as interesting in and of themselves. What really goes on in paragraphs such as this one is that while it allegedly is about the Saami, the Saami are actually registered among the infrastructural conditions under which the farmers are living. In the deep structure of the narrative, the Saami are at best likened with the forest in which the peasants $\log$ timber or the soil the farmers plough. At worst they are portrayed as hindrances or enemies to the farmers, the true protagonists of the tale (cf., e.g. TH2, 300 and 303).

This omnipresent farmer's perspective on the history is strikingly visible in an illustration in the second volume. This illustration is significant because as the Saami are given so little space, there are of course also few illustrations for this topic. The ones that are in fact dedicated to Saami affairs are therefore of interest. The illustration is placed in one of the few articles that discuss the Saami in the second volume, and the caption reads: 'Much suggests that the characteristic Heimdalhaugen mountain in Harran was the border between agriculture and hunter culture in the Middle Ages. Further into the Namdalen Valley lay the 'Finnmark' [lit. 'Saami land'] where the Saami ruled' (TH1, 249). The photograph in full colour depicts a farmland with farms houses, cultivated fields and a church in the foreground and far away in the background lies 'the characteristic mountain'-with the landscape in which the Saami lived on the far side of the mountain, and so not depicted at all. What really is depicted here is in fact the peasant perspective itself, the very way of seeing the world that underpins the entire book (Fig. 8.1).

The domination of this peasant perspective may be understood as a reflection of how Norwegians in general, and the Norwegian historians in particular, are thinking. This way of thinking is also evident on a linguistic level. ${ }^{4}$ Due to historical conditions, the Norwegian language is dependent on certain economic and social suppositions that have implications for identity policy. These tendencies are heightened and sharpened by some of the writers in this volume. A key concept in the narrative is the term 'bebygd/bebyggelse'. This is used throughout the volumes, with the basic function of delineating the thematically relevant parts of the geography. At the same time, this concept has clear connotations which work to close off and exclude a nomadic culture. In English, this term is most usually translated into 'inhabited/habitation', but the Norwegian term or concept 'bebygd/bebyggelse' is more closely linked to buildings and permanent dwellings. However, an area may be inhabited even if there are no permanent buildings, and the landscape may be in use even if nobody actually resides there. In Trøndelags historie, however, the question is reduced to whether

${ }^{4}$ For an extended discussion of this, see Sem (2017). 
skjellige tider. Men forskerne er enige om at disse områda lengst nord og est i Trondelag var samiske områder også i middelalderen. Sporsmålet er om det budde samer lenger sorover. Ut fra kildene er det verre ả si noe sikkert om det, og vi skal ta opp sporsmälet seinere.

Det ser ut til at gärdsbusettinga i hoveddalforet ved Namsen strekte seg nordover til Solem og Aunet i Harran for svartedauden. Øst for disse gárdene ligger det karakteristiske fjellet Heimdalhaugen, fjellet har et samisk navn, Aajmehtalie, som ser ut til ả være innlảnt fra norsk for vikingtida. Og da kan det se rimelig ut at den uklare grensa mellom jordbrukskulturen og jakt- og fangstkulturen lả i dette området i middelalderen. ${ }^{29}$

I alle fall betydde dette at bondene i Lierne og Grong mátte ha kontakt med jakt- og fangstkulturen hos samene. Det kunne vere konkurranse om jakt- og fiskeplasser, men det er ogsả sannsynlig at bønder og samer handla med hverandre, bytta varer og sảleis kjente kulturene til hverandre. I forste delen av denne boka har arkeologene pekt på at slik kunnskap og kontakt kan gå svært langt tilbake i tid.
Mye tyder på at det karakteristiske fjellet Heimdalhaugen i Harran var grensa mellom jordbrukskultur og fangstkultur $i$ middelalderen. Lenger innover i Namdalen var det efinnmarkw der samene ràdde.

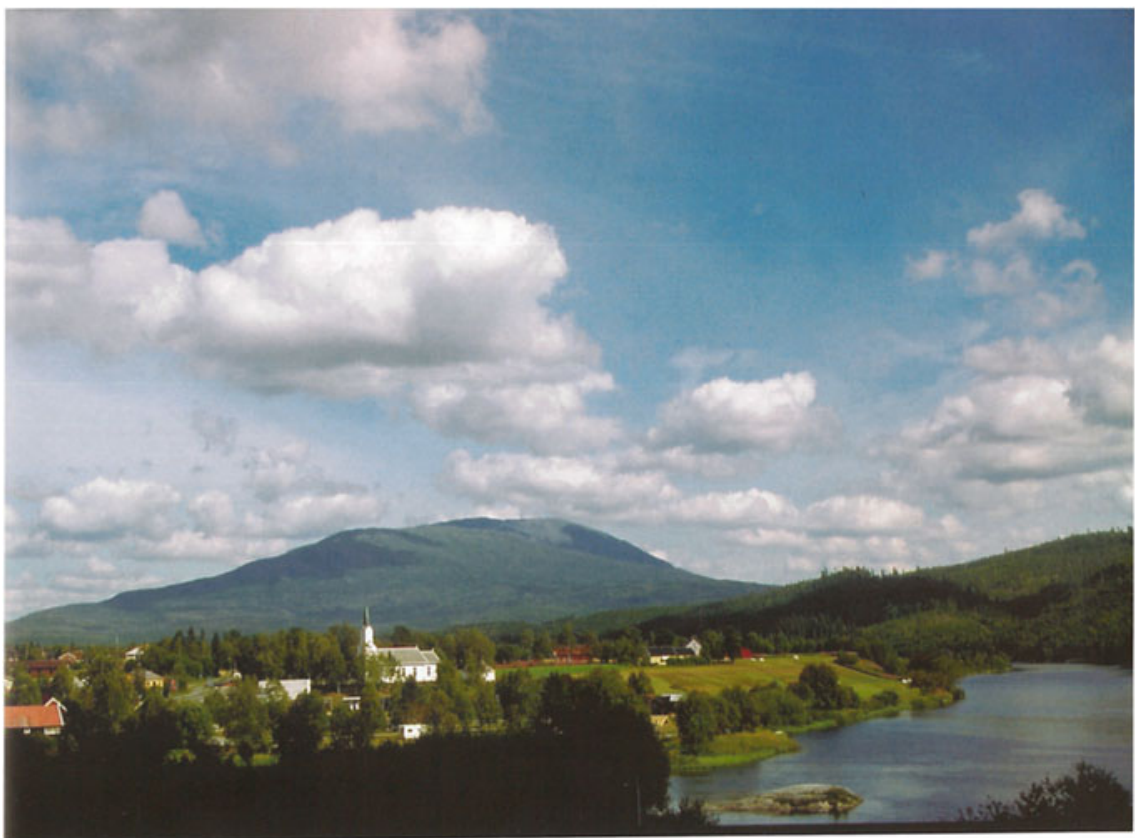

249

Fig. 8.1 Facsimile from Trøndelags historie, Vol. 1, p. 249. This is one of the very few illustrations dedicated to Saami topics in the volume. Ironically, the Saami landscape is located on the far side of the mountain in the background and therefore not depicted at all

farms are built there or not. This exclusive language is used and affects the minds of both readers and writers, probably without many of them even being aware of this. In some cases, though, the writers allow themselves to be taken captive and led astray by the language without giving any resistance or afterthought. The writers may, for instance, discuss an unsetteled area, or an area abandoned by farmers due to the Black Plague in the fourteenth century, and thoughtlessly slip over to referring to it as 'desolate' ['folketom']: 'By the Big Lake, called pórkvislir by the Norse, a tiny settlement was established in the Viking Age or perhaps a bit sooner [...]. Here 
no man lived the first few hundred years after the Black Plague. And such was also the case for the highlands between Snåsa and Grong' (TH1, p. 233). ${ }^{5}$ These areas are today Saami heartland, and it is questionable if this area, well suited to reindeer husbandry and a natural road to travel, really was so totally desolate, even if farming had been abandoned. However, this is taken for granted, and so is the total correlation between farming and living.

The Saami are also excluded from other concepts that work as a basis for the thinking of the text and its understanding of what constitutes a society. The term 'jordbruk' ['agriculture'] is one such example. Here this is invariably synonymous with farming/farms, with the cultivation of crops and husbandry of cattle (e.g. TH3, p. 39; TH2, p. 299). The chapter entitled "'Trønder" agriculture' fails to mention the Saami. Here it is unclear whether this is because the Saami are not 'Trønders' or that they are not agriculturalists. At any rate, the effect is that one characteristic feature that may very well define the agriculture of the region of Middle Norway from other regions is erased: the existence of reindeer husbandry. These examples show how deeply the farmer's perspective is woven into not only this book, but into the very Norwegian language itself. It is more than a red thread throughout the book. Indeed, it is actually the very wool of which the yarn is spun.

On the grammatical level too, the peasant perspective permeates the language. In paragraphs where both Saami and non-Saamis are described, the grammatical structures of the sentences underline that the farmers are the ones who act, as they are the subjects in the sentences. The Saami on the other hand, are usually objects, grammatically speaking. Sentences such as the following are typical: 'Demographic increase, re-clearing of farming soil and expansion of settlements [...] brought the Trønder farmers into closer contact with the Saami in the area'. Another example is: 'In Snåsa the farmer traded with the mountain Saami' (TH2, p. 264 and p. 325). This almost invariable grammatical pattern serves to underline the role of the Saami as dominated and passive, mere objects to be handled. ${ }^{6}$

In a remarkably large portion of the references to trading of customs and knowledge over the cultural borders, this is depicted as one-way traffic, and it is the Saami who have adopted from the Norsemen. For instance, it is explained how 'the Saami population could get hold of objects from the Norse settlers that they could use in their own pursuit of a livelihood', or 'there are examples of Saami annexing Norse burial customs' (TH1, p. 126). ${ }^{7}$ Not being a historian, I cannot repudiate these particular examples, but one can certainly point out that it is peculiar how unilaterally this communication is portrayed here. No symbiosis is suggested, nor is it suggested that the Saami invented things that the Norsemen have adopted. The narrative is stuck in

\footnotetext{
${ }^{5}$ Orig.: «Inne ved Storvatnet, det gamle pórkvislir, mellom Rissa og Leksvika oppstod det ei lita grend i vikingtida eller kanskje litt før [...]. I denne grenda budde det ikke folk de første hundreåra etter svartedauden. Det gjorde det heller ikke på Snåsaheia mellom Snåsa og Grong».

${ }^{6}$ Orig.: «Folkeveksten, gjenryddingen av gårder og ny utvidet bosetning inn mot gammel utmark og opp mot fjellet brakte trønderske bønder i nærmere kontakt med samene i distriktet»; «I Snåsa handlet bøndene med fjellsamene».

${ }^{7}$ Orig.: «en samisk befolkning kunne få tak i gjenstander i det norrøne miljøet som de kunne bruke i sin næringsutøvelse», eller at «[d]et fins eksempler på at samer har annektert norrøne gravskikker».
} 
firm figures of thought that lock the interpretations—and most probably affect the readers in turn.

The Saami, to a significant extent, are robbed of power and agency in many ways, and even erased from the history in many contexts. At one point, Volume II cites a 1683 source about the historic Levanger market, which mentions that this border market attracted about 1500-1600 'Swedes' from the far side of the border. The source then goes on to specify 56 different trading items, including reindeer skins, so-called finn dresses, finn boots, finn gloves and so on. The Finns/Saami themselves, however, are omitted from the story. The cleansing of the Saami in this more than 330 -year-old source is important, but hardly surprising. However, more ought to be expected in a 2005 book written to give a comprehensive account of the multifarious history and identity of the region. But never mind, their trading goods are still left to enrich the culture of the Trønders even as the Saami as human beings are erased from the history.

Consider another example, this time an illustration in the third volume, which covers the period from 1850 until the present day. I would like to point out here that the authors of this volume clearly and explicitly are more conscious of and sympathetic to the inclusion of Saami history. However, these authors are also-in the practice of their history writing - restricted, or restrict themselves, according to the tradition and conventions of historians. This volume includes an illustration of a man conducting a phrenological examination (i.e. a skull measurement) on a Saami family, allegedly during the 1920s (Fig. 8.2).

The caption ends: 'Dr. Jon Alfred Hansen Mjøen is second from the right' (TH3, p. 206). None of the other individuals depicted are named. Of course, there are many things to be said about this picture, let alone the historical motif. And of course, the writer of this part of the volume clearly is a critic of this practice. For instance, she writes: 'the Saami were among those exposed to such examinations', ${ }^{8}$ pointing out how humiliating and abusive this anthropological practice was. Nevertheless, it is not inconsequential that the scientist, a well-known Norwegian racial biologist, is the only one mentioned by name in this 2005 account. Even if the scientist is mentioned to shame him, this caption nevertheless reiterates a historical practice where the people in the Saami family are treated as specimens. They are presented here as victims, but at the same time as representatives of the Saami people-still robbed of their individuality. The reason why is to be found in the conventions of the handicraft of the historians. As powerful as this picture and these words are within this volume, the impact would probably be even greater if the author had given them their names.

\footnotetext{
${ }^{8}$ Orig.: «Samane var blant dei som vart utsette for slike målingar».
} 
Antropologiske undersokingar med blant anna skallemáling låg i tida. Samane var blant dei som vart utsette for slike málingar. Her er vi på Storelvavollen i Ridalen forst på 1920 . tallet. Dr. Jon Alfred Hansen Mjoen er nr. 2 frå hogre.

\section{Samiske organisasjonar}

Organisasjonar som er vanskelige å kategorisere, er dei samiske. Dei har sả mange aspekt ved seg: både økonomiske, kulturelle, politiske og sosiale. Samane organiserte seg i amtskrinsar. Først ute i heile landet var Nordre Trondhjems Amts lappeforening, stifta i 1906. Deretter kom tilsvarande for Søndre Trondhjems amt og for Nordlands amt. To sentrale personar i dette arbeidet var Elsa Laula Renberg og Daniel Mortenson. Grunnen til at sørsamane var først ute i organisasjonsarbeidet, var at dei vart hardast råka av reguleringane overfor reindrifta på slutten av 1800 -talet. Det gjorde at organisasjonstanken byrja vekse fram. Også på svensk side var det sørsamane som var først ute med organisering.

Daniel Mortenson sto også bak avisa Waren Sardne, som tyder "Fjellets tale». Det første nummeret kom i 1910. Programerklæringa for bladet gjekk ut på å ivareta samane sine interesser på alle måtar. I organisasjonane kom reindriftsnæringa og skulespørsmál til å stå sentralt. I februar 1917 vart det første landsmøtet for dei norske samane halde i Trondheim. Trondheim var eit naturlig val for eit slikt fellesmøte med tanke pả kor initiativtakarane høyrde heime. Elsa Renberg var drivkrafta, og i komiteen hadde ho med seg mellom anna Ellen Lie som arbeidde som sekretær for Dagsposten i Trondheim.

I 1918 følgde eit nytt landsmøte i Östersund. Riksgrensa var altså inga grense for samane, og det gjaldt også personlig både for bảde Renberg og Mortenson. I 1921 vart så det tredje landsmøtet halde, og no på nytt i Trondheim, men da hadde reindriftsinspek-

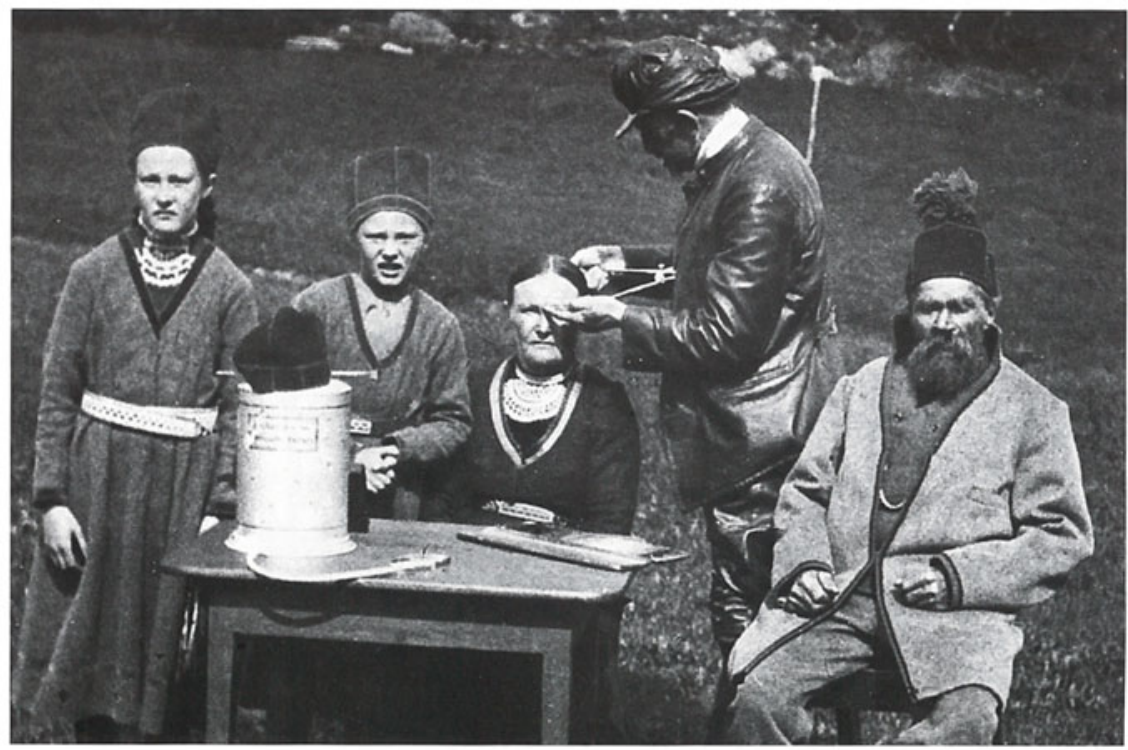

206 Aud Mikkelsen Tretvik FOREININGSÃNDA BREIER SEG

Fig. 8.2 Facsimile from Trøndelags historie, Vol. 3, p. 206. The illustration shows phrenological examinations of a Saami family in the 1920s 


\subsection{A Question of Sources?}

As mentioned above, the lack of sources on Saami history has been used by the editors as a defence against criticism. This defence or explanation is also reiterated time and time again throughout the volumes. Several of the writers point out that as an oral, nomadic culture, it is very hard to trace both their dwellings and their way of thinking (e.g. TH1, p. 277; TH2, p. 156). It is clear that this way of thinking is not entirely without grounds. However, these reiterations point away from the sources that actually do exist, and that very well could have been used more thoroughly and exhaustively. Some of these sources are mentioned in the pages of the three volumes without really being used to the full. And while large parts of the early agricultural history rest upon examination of Norse farm and place names, no validity is given to the many Saami topographical names, nor is any interest shown in them. Furthermore, a growing group of scholars has come to believe that many Saami dwellings actually have been found, but that they have been interpreted to be Norse dwellings due to the naturalized peasant perspective (Hermanstrand 2009, p. 489). When it comes to the hardships in finding sources: such is the case with every underprivileged group, e.g. women. In the latter case, great initiative is shown in digging up new source material. In the case of the Saami, however, one is content with stating the source problem as if it were a law of nature.

This invalidation of the voices of the Saami is also prominent when it comes to the contemporary, secondary sources. The question of who has rights to possess and use land is hotly debated, as mentioned above. The crux of this discussion is "who came here first?' As stated above, the volumes have been criticized for promoting the advancement of the Saami theory. The editors protested on this point in the ensuing debate: 'Read as a whole, the volumes do not unequivocally take sides when it comes to the one or other theory. Instead, we take a discussion position, aware of what may be read out of the written sources, while on the other hand aware that a lack of such sources does not necessarily mean a lack of people' (Stugu 2005). ${ }^{9}$ Stugu, in his position as co-editor, is correct in pointing out that different interpretations are referred to, but this is not the whole story. The place where this question is discussed in length is the second volume, and this discussion is clearly based on the works of Kjell Haarstad and Jørn Sandnes - the two most prominent and unequivocal advocates of advancement theory during the latter half-century. The writer does not, however, mention that their work has been severely criticized by others, neither is the reader presented to alternative explanations, other than a short comment saying: 'South Saami history has been eagerly debated in recent years' (TH2, p. 156). ${ }^{10}$ No alternative voices are heard or represented in the text, no alternative views are presented. The views of Haarstad and Sandnes are the basis of the account, and their

\footnotetext{
${ }^{9}$ Orig.: «Les ein bokverket Trøndelags historie som heilskap, tek ikkje det eintydig stilling for den eine eller den andre teorien, men inntek ein drøftande posisjon som på ei side tek omsyn til kva som er mogleg å lese ut av skriftlege kjelder, på den andre sida tek atterhald i at fråver av skriftlege kjelder ikkje treng bety fråver av menneske.».

${ }^{10}$ Orig.: «sørsamisk historie [har] blitt flittig debattert i de senere år».
} 
conclusions sum up the paragraph. The list of references for this paragraph also shows that of all the literature in this 'eager debate', only Haarstad and Sandnes are used (TH2, p. 441f). The thesis of Saami advancement may be said to have been somewhat modified, but it is equally true that this controversial theory that has laid the grounds for Saami losing rights to land in favour of farmer, is rendered without challenge in Trøndelags historie.

\subsection{Conclusion}

If the volumes are read carefully and critically, paying particular attention to how the writers treat the question of Saami people and culture, it seems obvious that the problem is not primarily a matter of sources, or the lack thereof. I would rather claim, as opposed to the editors, that the issue is indeed about political choices, in the sense of choices made on an ideological basis. It quite clearly is a question of power, and of the attribution of interest, value and belonging to the community. There is, on the other hand, little reason to suspect this political practice is malevolent, not even conscious. It is precisely this indifference that explains the discrepancy between the explicitly stated intentions to include the Saami in the Trønder history, and the way the text acts and actually works. The information and attitudes in the text, then, are dubious or shifting.

It is of course important to emphasize that this book is not alone in this attitude, indeed examples abound. To be sure, and as pointed out above, the libraries are replete with such history books, both regional like these, or local or national histories. However, it is especially worrisome to find this attitude in this particular work of history. It is especially worrisome because this work is of a recent date. I must confess that I myself have been a bit baffled during my research, as I would think most Norwegians would be when they are made aware of such textual practices still being applied in scholarly work in Norway today. Another reason for worrying is that the very intention of this book was to scrutinize the identity of the people of this particular region. Questions of identity and of belonging were at the heart of the project from the very outset. A book such as this is not only showing what a group of authors was thinking back in 2005, it has been written to create or strengthen a regional identity - in fact, a worldview. And I think it is fair to believe that to some extent it has been and still is effective. It has been widely read since its publication and has been used as a frame of reference and kind of state of the art by school teachers and county administrators in their work, to mention but a few. Last and not least this work of history gives us reason to worry because of the repeated requests made by the Saami stakeholders, including historians, archaeologists and the South Saami cultural centre, to be a part of this project. Their requests were denied from the outset, and still to this day, the authors, editors and the book committee have insisted on the adequacy of their treatment of South Saami history. Even when the text was criticized after it was published, they continue to insist that their way of including South Saami history and delineating the Trønder identity has not only 
been adequate but is the correct and proper way to go about it. In the debate about South Saami history, and specifically in this work of history, South Saami voices are seen as representatives of special interests, while non-Saami voices in contrast have been understood to represent a higher truth. The Saami are denied a platform from where to speak, and without a place in history, they are denied a platform for voicing their political demands and their very identity. In this piece of history, and therefore through this piece of history, the Saami population is placed on the very margin of society, not only geographically speaking. This book firmly establishes them as an outgroup. Trøndelag history indeed speaks volumes about the status and role allotted to the South Saami people within the region, partly through the story on the pages, partly through the story of the birth of the book.

By omitting Saami life in large parts of the history, the Saami are robbed of their identity and their links to the landscape and to society as a whole. In addition, the non-Saami are also robbed. Their lives and lifeworlds have also been shaped by the coexistence with a different group of people, both in tangible and intangible ways. Making visible the role that Saami culture and history have played in this region is important not only for the Saami communities, but is also of great value for the people outside the Saami communities. We will obtain a deeper understanding of our common history and of how the different identities have been constituted in different ways, but always in correlation to and in communication with each other.

As the editors of the three volumes of Trøndelags historie themselves point out, no work of history can ever tell the whole truth. The ambition of writing the whole story of the Trøndelag region can never be fulfilled. The pretence of giving a full and complete account is misleading, to put it mildly. There will always be details and perspectives that are omitted, and at all levels, alternative accounts and interpretations could be offered. The past itself has no beginning, nor an end, nor any other given demarcations. The very title of the volumes is an ideological stretching of any truth, as the name of the region is anachronistically superimposed on a terrain of the distant past, void of the political and ethnographic structures of today, in order to create a sense of narrative cohesion and of political effect. However, as a narrative figure and political tool, this claim is a kind of truth. As a political work, as a bedrock of identity, as a physical text, this claim is actively forming the minds of the 'Trønders' of today and of the future. As such, this work of history is the very foundation on which the truth and reality of future generations will be built.

\section{Bibliography}

Bal, Mieke. 1997. Narratology. Introduction to the theory of narrative. Toronto: University of Toronto Press.

Bergst $\varnothing 1$, Jostein, and Gaute Reitan. 2008. Samer på Dovrefjell i vikingtiden. Historisk tidsskrift 87: 9-27.

Bull, Ida. 2002. Trøndelags historie og sørsamene. In Adresseavisen 15/10/2002.

Bull, Ida. (main ed.). 2005a. Trøndelags historie I-III [The History of Trøndelag]. Tapir akademisk forlag. Trondheim. Co-editors Olav Skevik, Kalle Sognnes, Ola Svein Stugu. 
Bull, Ida. 2005b. Trøndelags historie og sørsamene. In Adressavisen [Trondheim daily] 29/11/2005. Bull, Ida. 2017. Samisk historie i Trøndelag. In Adresseavisen 17/02/2017.

Bull, Ida og Ola Svein Stugu 2008: Om samer i det sørlige Norge. Historisk tidsskrift 87: 657-664. O' Brien, Jean. 2010. Firsting and Lasting. Writing Indians out of Existence in New England. Minneapolis. University of Minnesota Press.

Dyrvik, Ståle. 1999. Norsk historie 1625-1814. Oslo: Det norske Samlaget.

Engen, Sigrun Berge. 2005. I mål med trøndersk fellesarv. In Adresseavisen 21/10/2005.

Ersland, Geir Atle, and Hilde Sandvik. 1999. Norsk historie 1300-1625. Oslo: Det norske Samlaget. Fairclough, Norman. 2003. Analysing discourse. Textual analysis for social research. London/New York: Routledge.

Fjellheim, Sverre. 2005. Trøndelag og samenes historie. In Adresseavisen 21/11/2005.

Furre, Berge. 1999. Norsk historie 1914-2000. Oslo: Det norske Samlaget.

Hermanstrand, Håkon. 2009. Sørsamisk historie. Historisk tidsskrift 88: 485-491.

Haarstad, Kjell. 1992. Sørsamisk historie. Ekspansjon og konflikter i Rørostraktene 1630-1900. Trondheim: Tapir.

Nerbøvik, Jostein. 1999. Norsk historie 1860-1914. Oslo: Det norske Samlaget.

Østerud, Øyvind. 2009. Evolving metaphors of development. In Brock-Utne, Birgit, and Gunnar, Garbo. (eds.) 2009. Language and power. The implications of language for peace and development. Mkuki na Nyota Publishers Ltd. Dar es Salaam.

Pryser, Tore. 1999. Norsk historie 1814-1860. Oslo: Det norske Samlaget.

Saemien, Sijte. 2005. Letter to NTNU University, dated 30/11/2005. Downloaded from https:// www.ntnu.no/styret/saker_prot/22.02.06web/O-6.06vedlegg.pdf. 01/03/2018.

Sandnes, Jørn. 1972. Om samenes utbredelse mot sør i eldre tid. Historisk tidsskrift 52: 113-137.

Sem, Leiv. 2017. Om framstillinga av sørsamar $i$ Trøndelags historie. Heimen 2-2017. Oslo: Universitetsforlaget, 130-144.

Sigurðsson, Jón Vidar. 1999. Norsk historie 800-1300. Oslo: Det norske Samlaget.

Skjesol, Hilde. 2002. Elleve plukket ut til å skrive trønder-historie. In Adresseavisen 10/05/2002.

Smith, Linda Tuhiwai. 2012. Decolonizing Methodologies. London and New York: Research and Indigenous Peoples. Second edition. Zed books.

Stugu, Ola Svein. 2005. Samar i Trøndelags historie. In Adresseavisen 29/11/2005.

Open Access This chapter is licensed under the terms of the Creative Commons Attribution 4.0 International License (http://creativecommons.org/licenses/by/4.0/), which permits use, sharing, adaptation, distribution and reproduction in any medium or format, as long as you give appropriate credit to the original author(s) and the source, provide a link to the Creative Commons licence and indicate if changes were made.

The images or other third party material in this chapter are included in the chapter's Creative Commons licence, unless indicated otherwise in a credit line to the material. If material is not included in the chapter's Creative Commons licence and your intended use is not permitted by statutory regulation or exceeds the permitted use, you will need to obtain permission directly from the copyright holder.

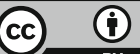

